\title{
Immunohistochemical Study of the Effect of Green Tea Extract on Methotrexate- Induced Oral Mucositis in Albino Rats
}

\author{
Al-Refai A Sultan ${ }^{1}$, Al-Barazenchy $\mathrm{H} \mathrm{Ali}^{2}$ and Khalil A Kamal ${ }^{2 *}$ \\ ${ }^{1}$ Department of Oral and Maxillofacial Surgery, College of Dentistry, Hawler Medical University, Erbil, Kurdistan Region of Iraq \\ ${ }^{2}$ Department of Oral Diagnosis, College of Dentistry, Hawler Medical University, Erbil, Kurdistan Region of Iraq
}

\begin{abstract}
Methotrexate (MTX) had been used for many years and complications usually encountered during treatment especially in cancer patients. The aim of the present study was to determine the preventive and early-stage anti cytotoxic effects of green tea on the histology of the rats cheek mucosa treated by high single dose of methotrexate.

The study included 36 Albino rats. Twelve animals were used in the pilot study to find the maximum toxic dose, and the other twenty four were divided into four groups: vehicle treated control group, green tea extract treated control group (40 mg/kg/day), Methotrexate treated group $(80 \mathrm{mg} / \mathrm{kg})$, and methotrexate and green tea extract treated group. Cheek mucosa excision was then performed. Histopathological examination was performed with hematoxylin-eosin, PAS and Masson's trichrome stains. Cell proliferation was examined using the Ki-67 antibody and anti apoptotic effect was determined based on Bcl-2 staining.

The result showed that in the methotrexate and green tea extract treated group, a significant increase in the thickness of the epithelium $(p<0.01)$, a significant decrease in the number of congested blood vessels in the connective tissue of rat cheek mucosa $(p<0.01)$, a non significant different in the Ki-67 expression $(p>0.01)$, and a significant increase in Bcl- 2 expression $(p<0.01)$ were seen in comparison with the methotrexate treated group.
\end{abstract}

In conclusion green tea extract at a concentration of $(40 \mathrm{mg} / \mathrm{kg} /$ day) produced protection against methotrexate induced oral mucositis by its antioxidant, antiangiogenic and anti apoptotic activity effects, and therefore can be used as a protective natural product to oral mucosa against methotrexate induced cytotoxicity.

Keywords: Methotrexate; Oral mucosa; Chemotherapy; Green tea; Cytotoxic drug; Oral mucositis

\section{Introduction}

Oral mucositis is an inherent complication of cancer therapy for many patients and plays a significant role in the physical and psychosocial aspects of patients undergoing cancer therapy. It is a larger problem than is currently recognized, and represents a therapeutic challenge frequently encountered in cancer patients because of significant number of patients affected by this side effect. The drugs used in chemotherapy like Methotrexate (MTX) destroy rapidly dividing cells in the body like the gastrointestinal epithelium, including the buccal epithelium [1,2]. This condition affects the quality of life and nutritional state of the patient who may require hospitalization thus increasing health care costs [3].

The pathophysiology for oral mucositis consists of five phases. The first phase is initiation (0-2 days), which occurs when chemotherapy is delivered. Direct damage to the epithelial cells injures the DNA and results in the death of a small portion of cells. Phase two is up regulation and message generation (2-3 days). In this phase, inflammatory cytokines are released that cause further tissue injury and cell death. The mucosa starts to thin, and erythema may be present. The third phase is signaling and amplification (2-10 days), which consists of direct damage to cells and escalation of the process initiated by proinflammatory cytokines. Phase four, ulceration (10-15 days), the ulcers tend to be deep and have no regular shape. A pseudo membrane frequently coats the lesions. In phase five, healing (14-21 days), the epithelial cells that border the ulcer begin to migrate to the ulcer where they proliferate into the wound bed [4].

Greater understanding of the pathobiology of mucositis has recently led the advent of targeted treatments for specific patient populations; however the treatment for oral mucositis remains palliative for most patients [5].
Tea, which is made from the leaves of the plant Camellia sinensis, is the most popular beverage worldwide besides water; it is rich in antioxidant polyphenolic flavonoids [6-8]. Epigallocatechin Gallate (EGCG), a green tea polyphenol, possesses potent antioxidant, antiapoptotic, anti-inflammatory, and autoantigen-inhibitory properties [9]. Oral mucositis has emerged as one of the most frequent causes of treatment delay and dosage reductions in cancer therapy, green tea may provide a mechanism to protect the oral mucosa in individuals undergoing cancer chemotherapy, but these possibilities have not been previously explored. For this reason the current study was aimed to evaluate the effectiveness of green tea extract $(40 \mathrm{mg} / \mathrm{kg} /$ day) as a preventive treatment for the induced oral mucositis by a high single toxic dose of MTX. As variables to evaluate the grade of damage or protection, we used histological and immunohistochemical investigations to clarify its effect on cell proliferation and cell apoptosis.

\section{Materials and Methods}

\section{Preparation of the extract}

Daily method of tea making (household preparation) from green

*Corresponding author: Ameera Kamal Khalil, Department of Oral Diagnosis College of Dentistry, Hawler Medical University, Erbil, Kurdistan Region of Iraq, Tel: 009647504882164; E-mail: amera1kam@yahoo.com

Received February 21, 2014; Accepted March 06, 2014; Published March 08 2014

Citation: Al-Refai AS, Ali ABH, Kamal KA (2014) Immunohistochemical Study of the Effect of Green Tea Extract on Methotrexate- Induced Oral Mucositis in Albino Rats. J Cytol Histol 5: 227. doi:10.4172/2157-7099.1000227

Copyright: (C) 2014 Al-Refai AS, et al. This is an open-access article distributed under the terms of the Creative Commons Attribution License, which permits unrestricted use, distribution, and reproduction in any medium, provided the original author and source are credited. 
Citation: Al-Refai AS, Ali ABH, Kamal KA (2014) Immunohistochemical Study of the Effect of Green Tea Extract on Methotrexate- Induced Oral Mucositis in Albino Rats. J Cytol Histol 5: 227. doi:10.4172/2157-7099.1000227

Page 2 of 7

tea (Alwazah Swan Brand 100\% pure Nett $225 \mathrm{~g}$ ) was used to prepare aqueous extracts. The aqueous extract was prepared in ratio 1:10 with the consideration of the absorption coefficient of green tea leaves (which is 2). Five grams of dried green tea leaves were grinded to pieces of diameter lower than one $\mathrm{mm}$ were poured with $60 \mathrm{ml}$ of boiling distilled water [10], and time was given for the extraction to cool down and the mixture was filtered first with a fine muslin cloth under pressure and the clear filtrate was dried in a water bath at $40^{\circ} \mathrm{C}$ until a paste was obtained, dissolved in distal water and used at a concentration of 40 $\mathrm{mg} / \mathrm{kg} /$ day [11].

\section{Animals and study design}

Thirty six healthy Albino rats of $250 \pm 25 \mathrm{mg}$ weight obtained from the animal house, College of Medicine, Hawler Medical University, were used for the study and kept under laboratory conditions and housed in a temperature-controlled environment $\left(21-24^{\circ} \mathrm{C}\right)$, maintained on a 12 $\mathrm{hr}$ light/12 hr dark cycle and given free access to food and water. The research project was approved by the Research Ethics Committee at College of Dentistry, Hawler Medical University under protocol.

In the pilot study, twelve animals were used to find the effect of different doses of MTX (Ebewe Pharma Ges, Austria- $50 \mathrm{mg} / 5 \mathrm{ml}$ ) on the rat buccal mucosa. The animals received intraperitoneal injection of MTX (three animals each): $10 \mathrm{mg} / \mathrm{kg}, 20 \mathrm{mg} / \mathrm{kg}, 40 \mathrm{mg} / \mathrm{kg}$, and $80 \mathrm{mg} /$ $\mathrm{kg}$ body weight respectively. In the second day of the experiment, all the animals were sacrificed by overdose of anesthesia, and biopsies from the buccal mucosa of the animals were taken, fixed and processed for H\&E.

\section{The results of the pilot study}

Results showed that when there was increase in the dose of MTX there was increase in the cytotoxic effect. After 48 hours, the MTX showed acute effect on rat buccal mucosa. In the MTX treated group that received $10 \mathrm{mg} / \mathrm{kg}, 20 \mathrm{mg} / \mathrm{kg}$, and $40 \mathrm{mg} / \mathrm{kg}$, there were increase in the thickness of the epithelium, and the number of sub epithelial inflammatory cells and congested blood vessels (Figure 1).
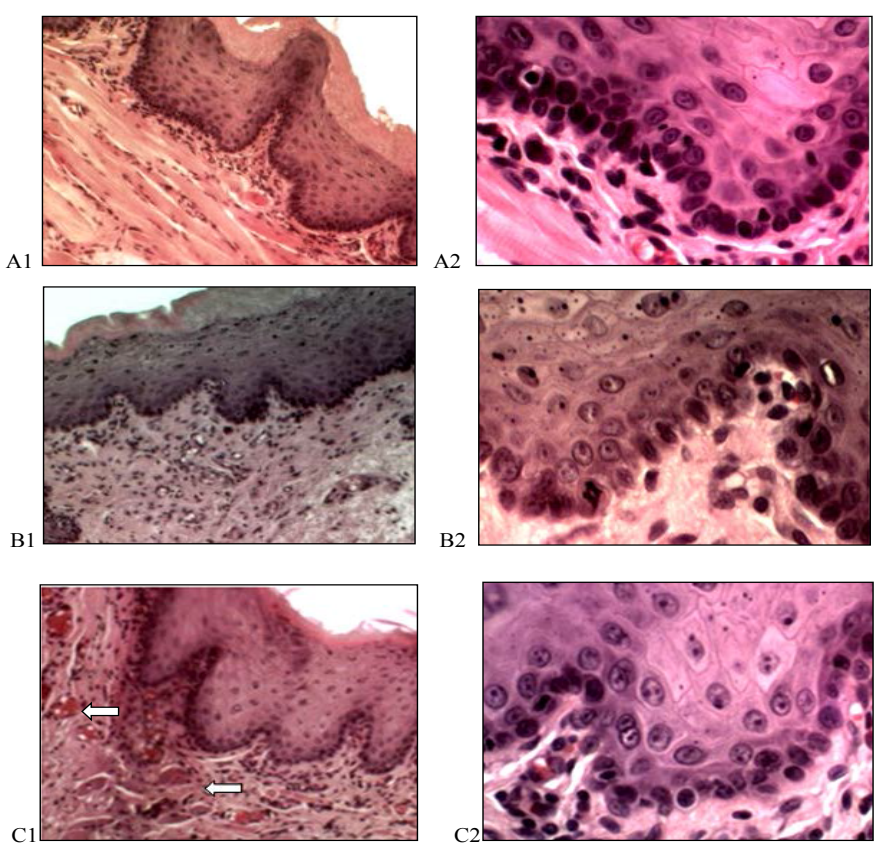

Figure 1: A photomicrograph of the buccal mucosa of rat treated by $10 \mathrm{mg} / \mathrm{kg}$ methotrexate $(\mathrm{A} 1, \mathrm{H} \& \mathrm{E} \times 100 ; \mathrm{A} 2, \mathrm{H} \& \mathrm{E} \times 400)$ showing increase in the thickness of the epithelium, $20 \mathrm{mg} / \mathrm{kg}$ methotrexate (B1,H\&E x100; B2,H\&E x 400) showing increase in the thickness of the epithelium and the number of subepithelial inflammatory cells and blood vessels, $40 \mathrm{mg} / \mathrm{kg}$ methotrexate (C1,H\&E x 100; C2, H\&E x 400), showing increase in the thickness of the epithelium and the number of subepithelial inflammatory cells and congested blood vessels (arrows).

A
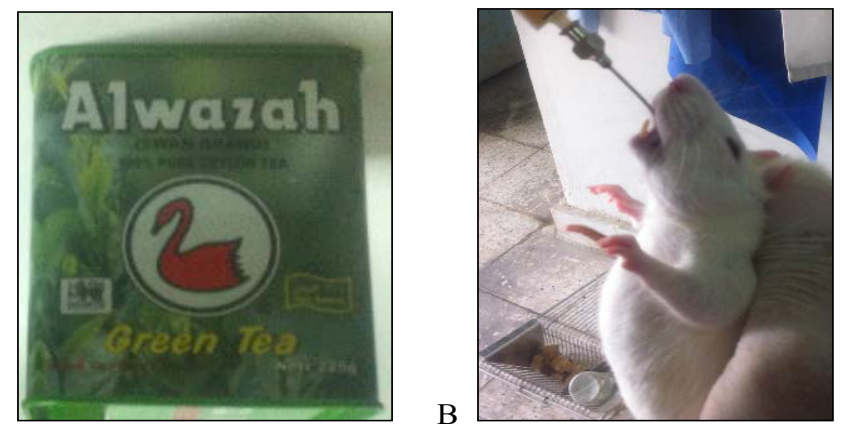

Figure 2: (A) Alwazah green tea used in the study. (B) Oral administration of green tea extract by intragastric gavage needle. 
Citation: Al-Refai AS, Ali ABH, Kamal KA (2014) Immunohistochemical Study of the Effect of Green Tea Extract on Methotrexate- Induced Oral Mucositis in Albino Rats. J Cytol Histol 5: 227. doi:10.4172/2157-7099.1000227

The result of pilot study also showed that the maximum toxic effects of the drug were seen in the buccal mucosa of rats treated by $80 \mathrm{mg} /$ $\mathrm{kg}$ of MTX, as seen in Figure 2. For this reason the other twenty four animals were randomly divided into four groups (six animals/cage):

Group 1: Vehicle treated control group: A volume of distilled water equal to green tea extract was administered orally two times daily by intragastric gavage needle for five days, and physiological saline $(0.9 \%$ $\mathrm{NaCl}$ ) was administered intraperitoneally in similar dose of MTX after 72 hour from the beginning of the experiment.

Group 2: Green tea extract treated control group: The extract of green tea $(20 \mathrm{mg} / \mathrm{kg})$ was administered orally two times daily (total 40 $\mathrm{mg} / \mathrm{kg} /$ day) by intragastric gavage needle for five days, and physiological saline $(0.9 \% \mathrm{NaCl})$ was administered intraperitoneally in a similar dose of MTX after 72 hour from the beginning of the experiment.

Group 3: MTX $(80 \mathrm{mg} / \mathrm{kg})$-non green tea extract, treated group: The distilled water was administered orally two times daily for five days, and the animals received intraperitoneal injection of MTX after 72 hour from the beginning of the experiment.

Group 4: MTX $(80 \mathrm{mg} / \mathrm{kg})$ and green tea extract, treated group: The green tea extract $(20 \mathrm{mg} / \mathrm{kg})$ was administered orally two times daily throughout the five days of the experiment, but the intraperitoneal injection of MTX was done after 72 hour from the beginning of the experiment.
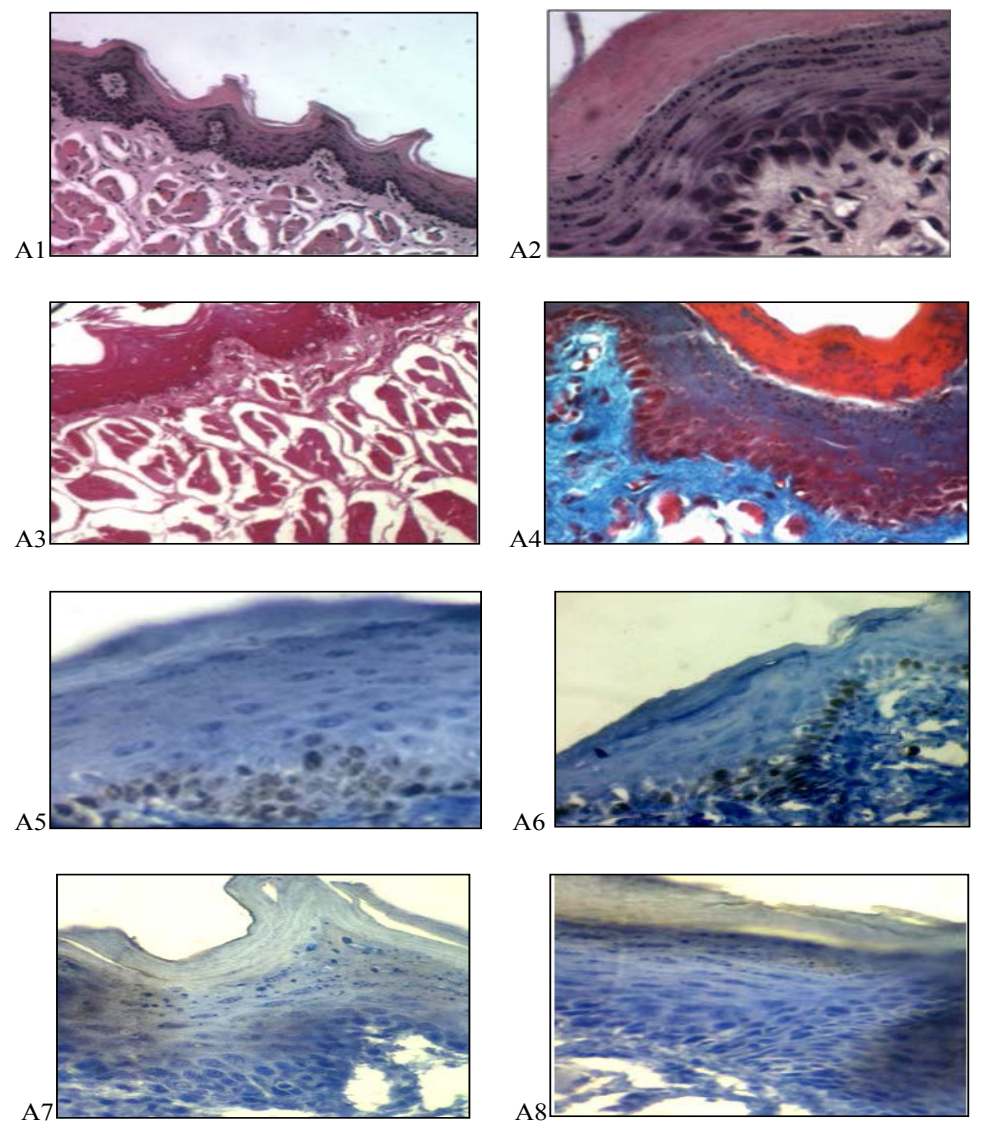

Figure 3: A photomicrograph of buccal mucosa of rat in the control groups, revealed normal keratinized squamous epithelium with columinar basal cell layer and normal connective tissue (Al, H\&E, x100; A2, H\&E, x400), the muscles appear red (A3, PAS x100), ), and the collagen fibers appear blue in color in the connective tissue (A4, Trichrome $\times 400$ ). Moderate $\mathrm{Ki}-67$ immuno reactivity in nuclei of cells of basal and suprabasal cells layersin the first and second group respectively (AS, A6, immunohistochemistry $\times 400$ ), and mild cytoplasmic reaction to Bc1-2 in epithelial cells of the first and second group respectively (A7, A8, immunohistochemistry $x 400$ ). 
Citation: Al-Refai AS, Ali ABH, Kamal KA (2014) Immunohistochemical Study of the Effect of Green Tea Extract on Methotrexate- Induced Oral Mucositis in Albino Rats. J Cytol Histol 5: 227. doi:10.4172/2157-7099.1000227

primary antibody, for use with Dako EnVision ${ }^{\mathrm{TM}}$, EnVision ${ }^{\mathrm{TM}}$ double staining and LASAB ${ }^{\mathrm{TM}} 2$ systems. The staining procedure sections of the instructions included with each detection system were followed. Positive and negative controls were run simultaneously with biopsy specimen.

Positive cells expressing Ki-67 were identified by a brown precipitate in the nucleus except in mitotic cells, where the chromosomes and the cytoplasm are labeled, while Bcl-2 was demonstrated brown cytoplasmic staining. To ensure the objectivity of the analysis, the evaluation was carried out by 2 independent observers. Five sections were randomly chosen for each animal. Approximately 1000 cells from cell population were counted by two observers at a magnification of 400x (Olympus, Japan) and the percentages of ki-67 and Bcl-2 positive cells were calculated. The level of Ki-67 and Bcl-2 expression was evaluated according to the scoring system of Seleit et al. [13]. The application of this system gives a score ranging from 0 to 3 for both degree of positivity: percentage of positively stained cells [(absent: $<1 \%)$, (mild: 1-10\%), (moderate: 10-50\%), (strong: $>50 \%$ )]. For statistical analysis ANOVA test was used to compare the results. Level of significance was set as $\mathrm{p} \leq 0.01$.

\section{Results}

The rat buccal mucosa of the control groups demonstrated structural integrity of rat stratified squamous keratinized buccal mucosa with normal underlying lamina propria, no inflammatory cells infiltration was seen, and the basement membrane showed mild or short folding (Figure 3).
Microscopical features of rat's cheek mucosa in the MTX $(80 \mathrm{mg} /$ $\mathrm{kg}$ ) - non green tea extract treated group showed a decrease in the thickness of the epithelium, vacuolar degeneration of some epithelial cells, flattening or shortening of rete ridge, and destruction of some basal cells was also seen. Increase in the number of congested blood vessels in the connective tissue can be seen in this group only (Figure 4).

Microscopical features of rat's cheek mucosa in the MTX $(80 \mathrm{mg} /$ $\mathrm{kg}$ ) - green tea extract treated group $(40 \mathrm{mg} / \mathrm{kg} /$ day $)$ showed increase in the thickness of the epithelium, the epithelium restores its integrity and revealed marked improvement (Figure 5). Inflammatory infiltrates were observed in the study groups samples. Histopathological examination of the cheeks mucosa that was excised from the rats in all groups showed no evidence of collagen fiber breakdown or fibrosis.

There was a statistically significant difference $(\mathrm{P}<0.01)$ present between group $3(16.3 \pm 2.264)$ and the other three groups regarding the thickness of the epithelium, but a statistically no significant difference $(\mathrm{P}>0.01)$ was observed between group $1(42 \pm 2.655)$ and $2(43.2 \pm$ 2.513), 1 and 4 (45.4 \pm 4.066 ) or between group 2 and 4 .

In addition to that, there was a statistically significant difference $(\mathrm{P}<0.01)$ present between group $3(9.138 \pm 0.798)$ and the other three groups regarding the number of congested blood vessels, but a statistically no significant difference $(\mathrm{P}>0.01)$ was observed between group $1(3.416 \pm 0.487)$ and $2(2.344 \pm 0.622)$, or between 1 and $4(2.783$ $\pm 0.343)$, or between 2 and 4 .

The Ki-67 immune staining results in the MTX and green tea extract
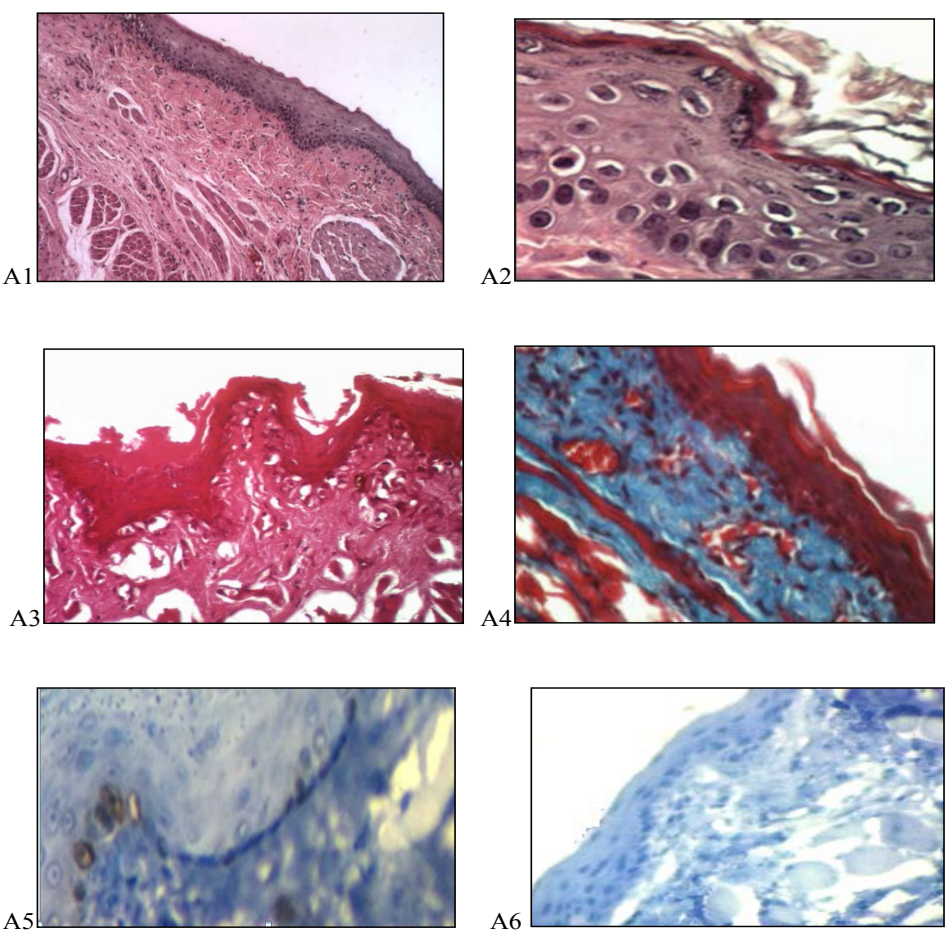

Figure 4: A photomicrograph of buccal mucosa of rat treated by $80 \mathrm{mg} / \mathrm{kg}$ methotrexate showing a decrease in the thickness of the epithelium and keratin layer, flattening of rete ridges ( $\mathrm{Al}, \mathrm{H \& E} \times 100)$, extensive cytoplasmic vacuolation of epithelial cells with hyperchromatic nuclei (A2, H\&E,x400), cytoplasmic vaculation most commonly seen at the tip of rete ridges (A3, PAS x100), with vascular hyperemia in the connective tissue (A4, Trichrome,x100). Immunohistochemical expression of ki-67 in the buccal mucosa of rat showing mild positive immunoreaction in some nuclei of basal epithelial cells (A5,immunohistochemistry $x 400)$. Negative immunohistochemical expression of Bc1-2 in the epithelial cells cytoplasm of the buccal mucosa of rats (A6, immunohistochemistry x100). 
Citation: Al-Refai AS, Ali ABH, Kamal KA (2014) Immunohistochemical Study of the Effect of Green Tea Extract on Methotrexate- Induced Oral Mucositis in Albino Rats. J Cytol Histol 5: 227. doi:10.4172/2157-7099.1000227
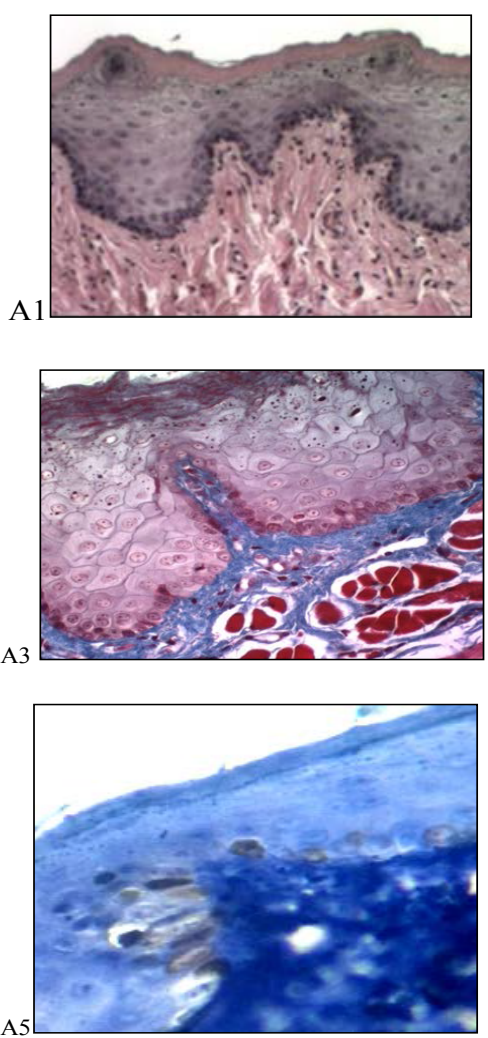
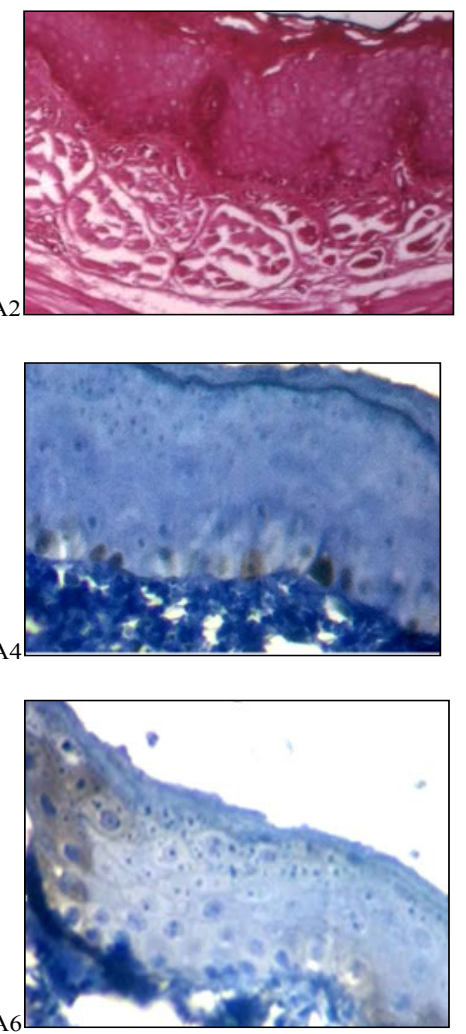

Figure 5: A photomicrograph of buccal mucosa of rat in the methotrexate and green tea extract treated group, showing that the epithelium restores its integrity and thickness but it cover by irregular keratine laver, no congested blood vessels can be seen in the connective tissue (Al, H\&E, 200 ; A2, PAS, $x 400$ ). The collagen fibers stained blue and the cross sections of muscles appear nearly similar to that of the control group and stained deep red ( A3, Trichrome $\mathrm{x} 400$ ). Immunohistochemical expression of ki-67 in the buccal mucosa of rat showing mild positive immunoreaction in the nuclei of basal and sunrabasal epithelial cells (A4, A5, Immunohistochemistry x 400). Mild positive immunohistochemical expression of Bc1-2 in the epithelial cells cytoplasm of the buccal mucosa of rats (A6, immunohistochemistrv $\times$ 400).

treated group showed mild positive Ki-67 immunoreactions. There was a statistically significant difference $(\mathrm{P}<0.01)$ present betweengroup 1 $(21.633 \pm 1.479)$ or group $2(22.786 \pm 1.223)$ and the other two groups in terms of the rate of proliferation, but a statistically no significant difference $(\mathrm{P}>0.01)$ was observed between group $3(1.216 \pm 0.254)$ and $4(2.07 \pm 0.401)$.

The Bcl-2 immune staining results in the MTX and green tea extract treated group showed mild positive Bcl-2 immunoreaction in the cytoplasm of some epithelial cells, but it was negative in the MTX treated group. There was a statistically significant difference $(\mathrm{P}<0.01)$ present between group 3(zero) and the other three groups in terms of the rate of anti apoptosis, but a statistically no significant difference $(\mathrm{P}>0.01)$ was observed between group $1(2.231 \pm 0.417)$ and $2(2.951 \pm$ $0.645), 1$ and $4(2.795 \pm 0.774)$ or between group 2 and 4 .

\section{Discussion}

MTX, a folic acid antagonist, is widely preferred as a cytotoxic chemotherapeutic agent but the efficacy is limited due to its side effects [14].

The results of pilot study showed that the animals that received $10 \mathrm{mg} /$ $\mathrm{kg}, 20 \mathrm{mg} / \mathrm{kg}$, and $40 \mathrm{mg} / \mathrm{k}$ of MTX, there were increase in the thickness of the epithelium and the number of sub epithelial inflammatory cells and congested blood vessels. In the initial inflammatory/vascular phase of mucositis, the epithelial, endothelial, and connective tissue cells in the buccal mucosa release free radicals, modified proteins, and proinflammatory cytokines, including interleukin-1B, prostaglandins, and Tumor Necrosis Factor (TNF). These inflammatory mediators cause further damage either directly or indirectly by increasing vascular permeability and angiogenesis, thereby enhancing cytotoxic drug uptake into the oral mucosa [1].

The result also showed that, when there was increase in the dose of MTX the cytotoxic effect increased. A photomicrograph of buccal mucosa of rat treated by $80 \mathrm{mg} / \mathrm{kg}$ MTX showed a significant decrease in the thickness of the epithelium. The direct inhibitory effects of chemotherapy on DNA replication and mucosal cellular proliferation result in reduction in the renewal capacity of the basal epithelium [15]. In addition to that, there was increase in the number of connective tissue congested blood vessels. In the initial phase, the chemotherapy causes the release of cytokines from the epithelium and the connective tissues which incite an inflammatory response that may result in increased sub epithelial vascularity. This phase is considered to be relatively acute [16].

Munaretto et al. [2] immune suppressed the mice with the subcutaneous injections of $2.5 \mathrm{mg} / \mathrm{kg}$ MTX for three consecutive days, the epithelial thickness of the ventral surface of the tongue was increased significantly in the second day of the experiment, but it decrease gradually later on. The number of blood vessels and inflammatory cells per field in the connective tissue was similar in control and experimental samples. The differences between the present result and other results in the methodology used prevent a direct comparison between them. 
In the MTX and green tea extract treated group the epithelium was significantly increased in thickness in relation with the methotrexate treated group. Green tea polyphenol, possesses potent antioxidant property and can protect against oxidative stress and prevent damage to cells [17]. In addition to that, the connective tissue showed significant decrease in the number of dilated and congested blood vessels in relation with the MTX treated group, thus the blood flow to the oral mucosa were reduced, thus reducing the availability of chemotherapeutic agents to the oral mucosa. This could be due to the anti angiogeneic property of green tea [18-20].

Despite the availability of many therapeutic agents that claim to prevent or reduce the severity of oral mucositis, no intervention that is completely successful at preventing oral mucositis exists. In the present study the combined treatment of MTX and green tea extract ameliorated the histological changes in the buccal mucosa induced by MTX alone. In addition to the antioxidant action and anti angiogeneic property of green tea, it also contains carotenoids, tocopherols, vitamin $\mathrm{C}$, vitamin $\mathrm{E}$, minerals such as $\mathrm{Cr}, \mathrm{Mn}, \mathrm{Zn}$, and certain phytochemical compounds, which can decrease the severity of oral mucositis. The essential nutrient vitamin $\mathrm{E}$ in green tea acts as an antioxidant, its role is to protect against damage by free radicals and could increase green tea antioxidant potential [21]. Vitamin E in combination with vitamin C both act on a cellular level by protecting the cell membrane and preventing peroxidation [22]. Khurana et al. [23] also found that vitamin E can be used for treatment of oral mucositis. Furthermore green tea has antibacterial, antiviral and antifungal activity against Candida albicans and can also decrease the severity of oral mucositis [24].

$\mathrm{Ki}-67$ is a nuclear proliferation-associated antigen expressed in the growth and synthesis phases of the cell cycle but not in the resting phase. This antigen provides information about the proportion of active cells in the cell cycle [25]. In the controlled groups, the Ki-67 expression was mostly seen in the basal and supra basal epithelial cells, this suggests that the epithelial basal and supra basal compartments have controlled proliferation rate but with a continuous proliferative capacity. In the MTX treated group a significant reduction in the Ki-67 immune expression labeling index was noticed. But in the MTX and green tea extract treated group, the epithelium restores its integrity and revealed marked improvement with a non significant increase in the labeling index of Ki-67. The green tea strengthens the immune system action, prevents immune suppression and decreased the levels of 8-oxo-deoxyguanosine (8-oxodG), a marker of oxidative DNA damage [26]. Poly phenols or EGCG can be used in conditions characterized by altered metabolism or cellular activity and elicit cell differentiation. Hsu et al. [27] found that keratinocytes which exhibited low basal cellular activity showed renewed DNA synthesis up to 37 fold upon exposure to polyphenol or EGCG.

The bcl-2 gene encodes a protein located in the nuclear membrane, on the inner surface of mitochondria, and the endoplasmic reticulum. It is the most important gene of the bcl-2 family and has been reported to prolong the survival of cells by specifically inhibiting apoptosis. The balance between mitotic activity and apoptosis is thought to regulate normal development [28]. Results from the present study showed that bcl-2 protein does not seem to be involved in the control groups, since mild immunoreactivity was seen; these results suggest that loss of the bcl-2 anti-apoptotic control may be associated with a concomitant loss of other pro-survival molecule or an increase in the pro-apoptotic molecules in oral epithelium [29]. In the MTX-non green tea extract treated group, no immunoreactivity for Bcl- 2 was seen. But mild Bcl-2 expression in the MTX and green tea extract treated group was seen.
The epithelial cells may respond more frequently with arrest or senesce than with apoptosis.

In conclusion, the results showed that with the administration of green tea extract at a concentration of $40 \mathrm{mg} / \mathrm{kg} / \mathrm{day}$, it protects the oral mucosa by increase the thickness of oral epithelium, decrease the number of congested blood vessels, and increasing significantly the anti apoptotic activity, it can be used as a criterion and can be used as a novel approach to decrease the cytotoxicity of MTX on oral mucous membrane, therefore can be used as a protective natural product to prevent oral mucositis in individuals undergoing cancer therapy.

\section{References}

1. Cawley MM, Benson LM (2005) Current trends in managing oral mucositis. Clin J Oncol Nurs 9: 584-592.

2. Munaretto JC, Ponzoni D, Haddad AS, Puricelli E (2011) Preliminary histological analysis of methotrexate induced oral mucositis; experimental study in mice. Passo Fundo 16: 144-148.

3. Georgiou M, Patapatiou G, Domoxoudis S, Pistevou-Gompaki K, Papanikolaou A (2012) Oral Mucositis: understanding the pathology and management Hippokratia 16: 215-216.

4. Sonis ST (2004) A biological approach to mucositis. J Support Oncol 2: 21-32.

5. Logan RM, Gibson RJ, Sonis ST, Keefe DM (2007) Nuclear factor-kappaB (NF-kappaB) and cyclooxygenase-2 (COX-2) expression in the oral mucosa following cancer chemotherapy. Oral Oncol 43: 395-401.

6. Bajerska J, Wozniewicz M, Jeszka J, Drzymala-Czyz S, Walkowiak J (2011) Green tea aqueous extract reduces visceral fat and decreases protein availability in rats fed with a high-fat diet. Nutr Res 31: 157-164.

7. Chandra AK, Choudhury SR, De N, Sarkar M (2011) Effect of green tea (Camellia sinensis L.) extract on morphological and functional changes in adult male gonads of albino rats. Indian J Exp Biol 49: 689-697.

8. Braicu C, Ladomery MR, Chedea VS, Irimie A, Berindan-Neagoe I (2013) The relationship between the structure and biological actions of green tea catechins. Food Chem 141: 3282-3289.

9. Gillespie K, Kodani I, Dickinson DP, Ogbureke KU, Camba AM, et al. (2008) Effects of oral consumption of the green tea polyphenol EGCG in a murine model for human Sjogren's syndrome, an autoimmune disease. Life Sci 83 581-588.

10. Armoskaite V, Ramanauskiene K, Maruska A, Razukas A, Dagilyte A, et al (2011) The analysis of quality and antioxidant activity of green tea extracts. Journal of Medicinal Plants Research 5: 811- 816.

11. Gawish AM, Ramadan S, A Hassan AM, Issa AM (2010) Morphometrical, histopathological, and cytogenetical ameliorating effects of green tea extract on nicotine toxicity of the testis of rats. J Cytol Histol 1: 1-7.

12. Bancrof J, Gamble A (2001) Theory and Practice of Histological Techniques. (5thedn), Churchil, Livingstone, NewYork, London.

13. Seleit IA, Asaad N, Maree A, Abdel Wahed M (2010) Immunohistochemical expression of p53 and $\mathrm{Ki}-67$ in cutaneous lupus erythematosus. J Egypt Women Dermatol Soc 7: 5-15.

14. Al-Moula AD, Al-Mashhadane F, Mammdoh JK (2012) Effects of 6-mercaptopurine on salivary glands in rabbit. Al-Rafidain Dent J 12: 266-273.

15. Lotfy AO, Zayed M (2009) Immunohistochemical study of the effect of nigella satival extract on chemotherapy induced oral mucositis in albino rats. Cairo Dental Journal 25: 159-166.

16. Naidu MU, Ramana GV, Rani PU, Mohan IK, Suman A, et al. (2004) Chemotherapy-induced and/or radiation therapy-induced oral mucositis-complicating the treatment of cancer. Neoplasia 6: 423-431.

17. Sener G, Eksioglu-Demiralp DE, Cetiner MErcan F, Sirvanci S, et al. (2006) L-carnitine ameliorates methotrexate-induce oxidative organ injury and inhibit leukocyte death. Cell Biol Toxicol 22: 47-60.

18. Cao Y, Cao R (1999) Angiogenesis inhibited by drinking tea. Nature 398: 381.

19. Pfeffer U, Ferrari N, Morini M, Benelli R, Noonan DM, et al. (2003)Antiangiogenic activity of chemopreventive drugs. Int J Biol Markers 18: 70-74. 
Citation: Al-Refai AS, Ali ABH, Kamal KA (2014) Immunohistochemical Study of the Effect of Green Tea Extract on Methotrexate- Induced Oral Mucositis in Albino Rats. J Cytol Histol 5: 227. doi:10.4172/2157-7099.1000227

20. Thakur VS, Gupta K, Gupta S (2012) The chemopreventive and chemotherapeutic potentials of tea polyphenols. Curr Pharm Biotechnol 13 191-199.

21. Yapar K, CavuÅŸoÄŸlu K, OruÃß E, YalÃßin E (2009) Protective effect of royal jelly and green tea extracts effect against cisplatin-induced nephrotoxicity in mice: a comparative study. J Med Food 12: 1136-1142.

22. Ludhwani S (2012) Oral mucositis management protocol by oral physician. International Dental Journal of Student 'S Research 1: 6-12.

23. Khurana H, Pandey RK, Saksena AK, Kumar A (2013) An evaluation of Vitamin $\mathrm{E}$ and Pycnogenol in children suffering from oral mucositis during cancer chemotherapy. Oral Dis 19: 456-464.

24. Cabrera C, Artacho R, Giménez R (2006) Beneficial effects of green tea--a review. J Am Coll Nutr 25: 79-99.
25. Lazar D, Taban S, Sporea I, Dema A, Cornianu M, et al. (2010) Ki-67 expression in gastric cancer. Results from a prospective study with long-term follow-up. Rom J Morphol Embryol 51: 655-661.

26. Zaveri NT (2006) Green tea and its polyphenolic catechins: medicinal uses in cancer and noncancer applications. Life Sci 78: 2073-2080.

27. Hsu S, Bollag WB, Lewis J, Huang Q, Singh B, et al. (2003) Green tea polyphenols induce differentiation and proliferation in epidermal keratinocytes. J Pharmacol Exp Ther 306: 29-34.

28. Ribeiro DA, Salvadori DM, Marques ME (2005) Abnormal expression of bcl2 and bax in rat tongue mucosa during the development of squamous cell carcinoma induced by 4-nitroquinoline 1-oxide. Int J Exp Pathol 86: 375-381.

29. Nafarzadeh S, Jafari S2, Bijani A3 (2013) Assessment of bax and bcl-2 immunoexpression in patients with oral lichen planus and oral squamous cell carcinoma. Int J Mol Cell Med 2: 136-142. 